\title{
Exploring “Her” Depictions of the 19th Century Social Transactions in Alcott’s Behind the Mask
}

\author{
S. Bokir
}

\begin{abstract}
Behind the Mask is one of Louisa May Alcott (1832-1888) successful short fiction, though did not reached the fame of the other novels like Little women, still it is considered one of the remarkable works of Alcott. In the novella, Alcott delivered a well representation of the social and economical positions of women in $19^{\text {th }}$ century; and how a lot of women were obliged to earn their living though they are from the genteel class.

Alcott depicts women's socio-cultural challenges in the $19^{\text {th }}$ century English society through her protagonist's struggle for a better social status against numerous social prejudices she encounters. In this paper, I will identify, explore and investigate these social prejudices through the theory of the intersectional feminism point of view that discusses the intersectionality of class and gender that has been shown to have a visible impact on the labor market for females in the $19^{\text {th }}$ century Europe.
\end{abstract}

Index Terms-Louisa May Alcott, Behind the Mask, intersectionality, feminism.

\section{INTRODUCTION}

American author Louisa May Alcott (1832-1888) in Behind the Mask is very successful in representing the social and economical positions of women in $19^{\text {th }}$ century. In general, women, in that era, were dependent financially on either their fathers or husbands. However, if the circumstances had obliged them to support themselves or their families, they would usually have searched for jobs. In her novel, Alcott depicts women's socio-cultural challenges in the $19^{\text {th }}$ century English society through her protagonist's struggle for a better social status against numerous social prejudices she encounters. In this paper, I will identify, explore and investigate these critical social prejudices through the theory of intersectionality and how sex and class are effecting the situation of women in the nineteen-century Europe. "intersectionality - the relationships among multiple dimensions and modalities of social relations and subject formations-as itself a central category of analysis" [1]

From the intersectional feminism point of view that discusses the intersectionality of class and gender has been shown to have a visible impact on the labor market for females in the $19^{\text {th }}$ century Europe. That was discussed in Alcott's novel behind a Mask by the portrayal of Jean trying to maintain her sense of self across from the prejudices she faces her as a woman from a lower class. Though governesses are usually comes from good families, still their need to work for money have given them a class of their own

Manuscript received June 9, 2017; revised September 10, 2017.

Shada Salem Bokir is with the National University of Malaysia (Universiti Kebangsaan Malaysia), Malaysia (e-mail: Shadabukier@yahoo.com). below.

The complexity that result from analyzing the subject expands to include various dimensions of society in actual everyday situations that requires different categories of analysis. In this case there is a requirement for a distinctive methodology to fulfill research complexity demands. Those demands could be very challenging, as other researchers of intersectionality can confirm. Typically, scholars prefer methodologies that more naturally contribute to the study of complexity. One of those flexible methodologies is Intercategorical (aka categorical) complexity

The intercategorical approach to intersectionality starts by focusing on the fact that inequality exists inside any social group, and then customizes this as a foundation for discussion of intersectionality [1]. According to intercategorical complexity, "the concern is with the nature of the relationships among social groups and, importantly, how they are changing." [1] Variations of this methodology utilize existing categorical distinctions to document inequality across multiple dimensions and measure its change over time. "The intercategorical approach (also referred to as the categorical approach) initially started with the inspection of unequal relationships among already established communities, as defective and continuously changing as they are, and those relationships become the center of analysis in such researches [1].

\section{DISCUSSION}

\section{Interlocking Matrix of Oppression}

Collins discusses the different intersections of social discrimination as the matrix of domination, which is also called, "vectors of oppression and privilege" [2]. These expressions are indicating how differences among people (sexual orientation, class, race, age, etc.) serve as oppressive methods against women and their life experience in society. Alcott in her novella Behind a Mask points towards the influence of such oppressive measures on working women in the society that connected to class and gender, and how it is further intensifying the women oppression in the society and their feeling of subordination.

The most familiar occupation for middle and upper-middle class women was to work as a governess, which was not an easy task for a gentlewoman to do, for a governess would frequently face many difficulties from low wages to loneliness and degradation. There were other occupations available for women at that time, but they were considered socially intolerable, such as sewing, writing or even acting [3]. Alcott, in this novella, highlights social attitudes toward governesses and actresses to criticize gender prejudices in 
her era.

In the $19^{\text {th }}$ century, the term governess was usually used to describe a private teacher usually for an aristocratic family [4] states that, "The governess is generally a young lady, dressed in the trappings of a working woman".

"The real definition of a governess, in English sense, is a being who is our equal in birth, manners and education but our inferior in worldly wealth” [4]. A governess was usually an unmarried woman who was responsible for educating the children in their early childhood. She was generally teaching them English, music, geography, math, drawing, singing and needlework, "According to the advice books, she must also teach Audrey plain and ornamental needle work, dancing, and drawing, as well as continuing the girl's lessons on pianoforte" [5]. A governess had to be a lady herself to teach the young aristocrats what they needed to know in order to be genteel nobles. This is why a governess usually came from a good family or at least a middle-class home. Unlike the nanny and nursemaid, who mainly are considered of inferior classes, the governess was from middle class or even the aristocracy [6]. Many governesses were daughters of clergymen too [7]. Those daughters were bright and well educated, like the Bronte sisters, Anne, Charlotte and Emily, three of Victorian England's greatest novelists, who worked in a period of their lives as governesses. The experience left them bitter and resentful. Similarly, "For Jane Austen, to become a governess was to "retire from all the pleasures of life, of rational intercourse, equal society, peace and hope, to penance and mortification forever" [8]. Austen here summarized all the psychological and financial pressures a governess may suffer, in being from a genteel family, who was living in a house that was not hers, and was obliged to take orders from people who could be from her own rank; in addition, she received money from her equals, all these circumstances could be very difficult for a governess to endure. In the same way, Charlotte Bronte wrote in a letter her experience as a governess saying,

I used to think I should like to be in the stir of grand folks' society; but I have had enough of it-it is dreary work to look on and listen [...] a private governess has no existence, is not considered as a living rational being, except as connected with the wearisome duties she has to fulfill [9].

Alcott portrays this in Behind a Mask, in the treatment the governess, Jean, received from the Coventrys; especially, from Gerald, the young Mr. Coventry, and his cousin Lucia. In the first chapter Gerald did not care enough to send a carriage to bring Jean home from the station, and leave her to walk for a long distance in late hour, an incident, which left Jean with much bitterness. Even the mother was portrayed to have some prejudice against the newcomer and judged Jean to be unpunctual before even meeting her though the time of the meeting was not due yet; Mrs. Coventry says; "Punctuality is such a virtue, and I know this woman hasn't got it, for she promised to be here at seven [...] Before she could get breath for another complaint, the clock struck seven and the doorbell rang. 'There she is!' Cried Bella” [10]. However, after meeting Jean, Mrs. Coventry's changes her attitude towards Jean. On the other hand, Gerald and Lucia's attitudes towards Jean are mischievous before and still after meeting her. Gerald commented when Lucia offered to tell him about the new governess:

- "No, thank you. I have an inveterate aversion to the whole tribe. I've often thanked heaven that I had but one sister, and she a spoiled child, so that I have escaped the infliction of a governess so long"

- "How will you bear it now?"

- "Leave the house while she is in it" [10].

Gerald's final remark is that he cannot even bear to stay in the same house with a governess. He would make other comments that refer to his disgust with the stranger like: "I will give her a three days' trial; if she proves endurable I shall not disturb myself; if, as I am sure, she is a bore, I am of anywhere, anywhere out of her way" [10]. Nonetheless, after making acquaintance with Jean, Gerald and Lucia's judgment did not change, as Lucia continues to make unkind statements about Jean; "What an uncomfortable creature to have in the house! I am sorry I urged her coming, for your mother has taken a fancy to her, and it will be hard to get rid of her" [10]. This attitude from her employers makes Jean hate them; and makes her determined to change her position. Both Gerald and Lucia made their comments about Jean without considering her feelings as she hears them, which make them very selfish and mean; and Jean has to put up with them and endure their insolence towards her as a governess, and an employee in their house.

Brandon wrote about Clair, Mary Shelly's stepsister, as she worked as a governess: "Governessing showed her the world. But it was never her world, and it filled her with bitterness" [8]. Moreover, a governess who received a salary from her employer was degraded from the genteel rank to a hired dependent. Her salary was considered very modest, about thirty-five pound a year, although this sum could vary according to how rich the employer was. She was offered a room and board as well. However, she was responsible for her medical care, travel expenses, and clothing; and she did not expect employment security. She was supposed to accompany the children as long as they were awake; therefore, another aspect from which the governess suffered was the work obligations, which left her lonely for most of the time. Because she was in a lower rank than her employers, she cannot socialize with them. And she is in a higher rank than the servants, which makes her unable to entertain their company, too,

The servants invariably detest her, for she is a dependent like themselves, and yet, for all that, as much their superior in other respects as the family they both serve. Her pupils may love her, and she may take the deepest interest in them, but they cannot be her friends. She must, to all intents and purposes, live alone [11].

All these aspects surrounding the position of a governess made women try to avoid working in such a career. But there were not many options for them to support themselves and their families. So, either they would learn to endure these circumstances of a governess, or try to find another way to secure their living. [11] So as governesses began to become a dominant figure in the 19-Century literature, and as writers become very fascinated by writing about them, this occupation becomes stereotyped in their novels. Some of the 
famous examples of governesses in literature are Jane Eyre (1943) and Agnes Grey (2009) by the Bronte sisters. When Jane was employed as a governess in Mr. Rochester mansion. The latter entertains a group of people who were making mean remarks about the role of governess and how they see it as a despised one. When the subject of governesses is opened, Blanche Ingram, one of Mr. Rochester's guests, declares "Mary and I have had, I should think, a dozen at least in our day; half of them detestable and the rest ridiculous, and all incubi-were they not, mamma" [12]

The governess figure continued to influence Victorian literature even more; "Her fall from bourgeois comfort, and her long journey to its eventual restitution, provide both an instant dramatic structure and a plethora of plot possibilities" [8]. Writers became fascinated by the Cinderella story of the poor governess who marries the house gentleman, like Thackeray’s Becky, Austen's Emma, and Bronte’s Jane Eyre. However, in real life, governesses usually did not have that a happy ending.

Alcott understood the stereotypical governess, and she played on that, in the way that when we read Behind a Mask we assume that the heroine will be the kind of female we are used to see in other literary works, the delicate, angelic female who suffers and is forced to work due to her difficult circumstances. But not for Alcott; she surprises us by making the governess a manipulative, deceiving woman, who tries to achieve some goals of her own at the expense of other people. Jean in Behind a Mask is a new shocking representation of a governess because of the stereotypical presentations of governesses in literature. Alcott portrayed Jean as a character who is totally dissatisfied by her position as a governess that she uses this position just as a ladder to get higher in social class. In this novella, though the heroine is manipulative and mean, readers tend to like her determination and we sympathize with her struggles against social prejudices.

After readers have been introduced to this governess, Jean, who succeeds in charming everybody in the Coventry household, she succeeds along with the readers themselves, we discover that this is not a typical kind of governess we are used to seeing in other forms of literature, but she is actually an actress disguised as a governess, in order to charm and marry a rich aristocrat. Again, affected by the stereotype of actresses in the period, that they are manipulative and deceptive, but Alcott twists that, she represents this actress as a woman who has very limited choices in the society that practices prejudice against women of class, this representation of Jean invites sympathy and readers began to wish that she will achieve all that she wants at the end. It is a measure Alcott's skill that she is able to get readers to overcome their probable prejudices about actresses and sympathize with them.

Society in 19-Century held a certain attitude towards actresses because they were known to be corrupted; as actresses were usually associated with prostitution at that period [13], [14]. The heroine of Behind a Mask, though a former actress, she tried her to hide her true identity from the Coventrys; she knew the reaction resulting from people knowing her career; society holds multiple prejudices against her because she is a woman, from a lower class, and her career is a degrading one. The intersectionality of prejudice pushed her to hide her identity and pretend that she is a young woman from a high-class family, and she is working as a governess. Jean here still suffers from the intersectionality of the society and the Coventerys in particular because she is a woman and a governess, which is less than the people who suppose to be her equal because she is their employee now. The only advantage that she can gain from this disguise is that she can still marry one of the young men in the family and thus climb the social ladder and be one of the family. But she does not have any chance as an actress to maintain a god social position; one night she was drunk and she confessed her secret to her future husband, Sydney, he abandoned her at once; Jean wrote to her friend: "I took too much wine, and I carelessly owned that I had been an actress. He was shocked, and retreated" [10]. Sydney here represents society's disapproval of acting as a career for women. She is an actress of thirty years old; she knows she is growing old for such a career, and that she will be out of business soon; she had to try to find another position to make a living that's why she disguised as a governess.

The economical and social status for actresses was even worse than that of governesses. The actresses' low wages usually were not worth the hard work; they had to perform for long hours, and they had to endure traveling with each show. Actresses suffered from disagreeable reputations in that society, where actresses were usually assumed to be wicked and dishonorable [13]. And though there were some exceptions of very famous actresses, who were wealthy and adored by people, the reputation of most actresses was not very pleasing. This has affected how they were presented in many of the literary works; they were portrayed as corrupted immoral figures. Authors not only condemned acting as a career for women, they also condemned the actress as a person and displayed the degradation she went through. They even demonstrated the humiliation she feels as an actress; In Behind the Scenes or The Actors by Lamplight (1879) the main character passionately cried out:

I am an actress-by law proscribed, by the church excommunicated! While I live women gather their skirts about them as I pass; when I die I am to be buried, as dogs are buried, in unholy ground...In the mean time, I am the recognized prey of the traditional property of him who will best pay me: an actress, with a body, God help her! But without a soul: unrecognized by the State, abjured by the Church, and utterly despised of all! [15].

The author, in the previous quotation, made Clarice condemn herself for being an actress in front of society, and declared her to be unworthy even to be buried as a human being when she dies. The truth is that it is the voice of society that was talking through Clarice, the society was condemning Clarice for being an actress, reference [16] states that the thoughts put in the theatre are the thoughts of the society itself, "Because the medium and social art involving the communication of ideology through living images, it tends to convey the ideology of the group that is dominant as producers and consumers of the images" [17]. The reputation the actress had in that time, made it impossible for society to be tolerant with the person who had such a career. Reference [18] indicates that, "In England tracts against the stage begin to appear in the 1570's, when theater for the first time 
becomes an officially sanctioned institution, rather than an impromptu, transitory affair." This statement in particular shows that the society had condom the institute as much as the people working in it. However, long before this date actresses had acquire this infamous reputation; Prynne marks, that in the classical theater Greek and Roman actresses "were all notorious impudent, prostituted Strumpets.”[19] On a similar note, "Pullen Kirsten, in her book Actresses and Whores: On Stage And in Society, studied the connections between actresses and whores from the $17^{\text {th }}$ century till now. She represented Elizabeth Boutell as an actress, who, according to Pullen, "used her epithet in order to draw attention to her own (and by implication, other women's) potential sexual agency" [1]. Thus, as a result of some actresses' behavior, which was considered disrespectful, it became common that any female who desired to work in this career might risk having the same reputation and be looked down upon by society.

In many situations, both careers acting and prostitution overlapped, to the point that makes it difficult to differentiate between the two. And this put actresses in a questionable position in front of a very conservative prejudiced society.

There were some historical incidents, which aroused the question of the integrity of the acting career for women. In the 19-century, several theaters were opened; most of these theaters were famous for having what was called the third tier: "Theaters in most American cities were designed expressly to house prostitutes in the third tier, but as quietly as possible” [14]. The third tier was known as a domain of prostitutes in a theater house and it was famous in American theaters to have such a gallery for prostitutes; "The primary business of the gallery was not to watch the play but to make arrangements for the rest of the evening. Having met in the tier, the prostitutes and their customers might go directly to a house of prostitution" [14]. Hence, the society condoms the spectators of theaters as much as the actresses, as they might carry the foul reputation of wanting to be there for the ladies not the show, Gosson positively declares that the typical theater audience enclosed of a number of whores, pimps, bawds, and eager customers” [20]. The epilogue to The Libertine draws in a related advertisement of the actresses' sexual availability:

Item, you shall appear behind our scenesis:

And there make love with the sweet chink of Guinees

The unresisted Eloquence of Ninnies.

Some of our Women will be kind to you, iLE?

And promise free Ingress and Egress too. [21].

Consequently, by having the actresses and the prostitutes in the same place, actresses had such a disgraceful reputation. Therefore, it was one of the most scandalous careers in the period; any woman who worked in such a career did not expect any social recognition or acceptance. In the prologue to Marriage A La Mode, Dryden writes that when many of the men in the audience departed to fight the Dutch,

The women sobb'd, and swore they would be true; And so they were, as long as e'er they could; ;

But powerful Guinee cannot be withstood,

And they were made of Playhouse flesh and blood [24].

The association becomes so obvious by then between prostitution and the theater that "playhouse flesh and blood" was interpreted easily into sexual illusion. [18]

The sexual implication of the theater and the acting career jammed mainly by females rather than male actors, Continental actresses were also distinguished for their exceptional sensual desires, and for their mercenary behavior. "In England, when actresses were not permitted on the stage, some sense remained of the necessary involvement of prostitutes with the theater" [18] these attitudes towards actresses in the eighteenth century compel Alcott's heroine in Behind a Mask to hide her past as a former actress in order to gain the family's sympathy and tolerance; she tries to begin her life with a more acceptable position, as a governess, but only to achieve her goals in marrying one of the gentlemen in the house. Jean uses the position of the governess as one of her performances as a role-play, in which she can achieve something else out of it. Jean says to herself after she retires to her room for the evening "Come, the curtain is down, so I may be myself for a few hours, if actresses ever are themselves” [10]. Jean here confesses that being a governess to her is only another acting scene to her. But doesn't Alcott here refer to women in general? Does Alcott think that women have to behave in a certain way to gain what they want and they have to act in order to please the society? Does Alcott mean that all women are actresses who take roles in their lives drawn for them by the society; they have to do things in a certain way?

The only option for a woman to achieve social and financial security in $19^{\text {th }}$ century society was getting married to a gentleman from the middle or the aristocrat classes. Women in that era did not enjoy a lot of freedom as a single woman, nor were there many choices for jobs to support herself. Therefore, marriage seemed to be the only solution for women in that era. This is why Alcott makes her heroine choose the financial security through marriage due to the limited choices for women at that time. Jean wanted to marry Sir John, the aristocrat patriarch of the Coventry family to get all at once the money and the social rank. She made plots and played games, but this is because she cannot reveal her true character when socializing with people.

Society, in $19^{\text {th }}$ century did, in fact, teach women to act in a certain way if they wanted to achieve a certain goal. If a woman wanted to get something from a man it was very hard and sometimes even impolite for a woman to confront a man openly or to be direct with him. She must be deceitful and clever: "Like any other group with limited control over their lives, women have always resorted to deceit as a survival technique. In the Victorian age deceit in matters large and small was a socially prescribed form of middle-class female behavior" [22]. Alcott recognizes this truth and applies it to her novel; as the heroine says to herself when she is alone: "I'll not fail again if there is power in a woman's wit and will” [10]. We can see how determined Jean is to achieve her goals, and that she will use all her powers and intelligence to make one of the gentlemen marry her.

Alcott in her novella tries to be very realistic in her observations about women's status and conduct in $19^{\text {th }}$ century. Her works were among many that highlight women's conditions and try to improve the miserable situations of women. This period as well witnessed the beginnings of Feminism, and the recognition of the need to improve women's situations. For that we can understand that Jean was not wicked in the way she gained her goals; she was 
only following the rules the society drew for her as a woman in a male dominant society. She tried to achieve her ambition with the use of manipulation; and she succeeded in marrying the old gentleman at the end as she wishes. Jean was an example of an oppressed middle-class female, and Alcott portrays her perfectly to represent women's attempts to survive the patriarchy.

However, married women had neither the basic freedom they have long dreamt of, nor the total financial security they needed; according to the laws of that time "Neither the Courts of Common Law nor of Equity could oblige a man to support his wife" [11]. Therefore, if a man refused to support his wife financially, she could not object or demand any rights, which sometimes made the fact of getting married not enough for a woman's financial security. Another unjust Law against women at that time was that "A husband can not give or grant any estate to his wife, either in possession, reversion, or remainder, though an exception under the Statute of Uses has been introduced” [22]. Such prejudiced laws intensified the miserable situations women suffered from during the $19^{\text {th }}$ century and did not leave enough choices for women to survive.

\section{CONCLUSION}

So even if the woman was married to a wealthy man she could not really enjoy much financial freedom, as she becomes under her husband's powers, who could at any time, deprive her of all material rights. Just in one case a woman perhaps can enjoy the material independence and that by having her fortune separated from her husband's: "after marriage, wealthy women who had separate estates were the most librated group of women in nineteenth-century England. These women could generally do as they pleased, and usually did" [22]. According to this, women could only achieve independence and libration by having a separate source of wealth. This is why Jean in the novella was longing for her husband to die, though handsome and nice. It was not because she hated him; it was simply because she was interested in his wealth in the first place that will guarantee her liberty and independence. In addition, becoming his wife gave her but little power, so in understanding all the social and financial issues of that period, Jean becomes a survival figure rather than a cruel manipulative person, and this is why she is much admired in this novel. Moreover, her ambition is for the full power, full control, and full independence, which make Alcott very truthful in her novel in stating the choices available for women in the $19^{\text {th }}$ century.

Alcott was realistic in her treatment of the events and the character's responses, especially the heroine's, who represented the $19^{\text {th }}$ century working woman, with her ambition for material equality with men and for the control of her own life. It could be that even Alcott was not pleased with Jean's options or her choices; however, she presented to the world a very powerful heroine, who could accomplish her dreams and overcome every other character, male or female, with her wit and persistence.

\section{ACKNOWLEDGMENT}

This research was supported by Sheikh Abdullah Boghshan, who always shows encouragement for knowledge and academic development. We thank our colleagues from
Hadhramuot organization, who provided insights and expertise that greatly assisted the research. I would also like to show my gratitude to Dr. Eric Olmedo for all his support and assistance through out the time of writing the research till publication.

\section{REFERENCES}

[1] L. McCall. The complexity of intersectionality. Signs: Journal of Women in Culture and Society (Chicago Journals), vol. 30, no. 3, pp. 1771-1800, Spring, 2005.

[2] G. Ritzer, Contemporary Sociological Theory and Its Classical Roots: The Basics, New York: McGraw-Hill. 2013, pp. 204-227.

[3] K. Hughes, The Victorian Governess, London: Hambledon and London. 2001.

[4] H. Michie, The Flesh Made Word: Female Figures and Women's Bodies, Oxford University Press, pp. 25-30, 1990.

[5] J. Klassen, The Silent Governess, Ada: Baker Pub. Group, 2010, p. 211.

[6] D. Copelman, London Women Teachers: Gender, Class and Feminism, 1870-1930, Routledge, pp. 17-18, 2013.

[7] W. F. Neff, Victorian working women, an historical and literary study of women in British industries and professions 1832-1850, by Wanda Fraiken Neff. New-York: Columbia University Press, p. 155, 1929.

[8] R. Brandon, Governess: The Lives and Times of the Real Jane Eyres. New York: Walker, 2008, pp. 2-7.

[9] H. Moglen, Charlotte Brontë: The self conceived. Madison, Wis: University of Wisconsin Press, 1984, p. 23.

[10] L. M. Alcott, Behind a Mask: The Unknown Thrillers of Louisa May Alcott. New York: Morrow, 1975, pp. 3-97.

[11] E. Rigby, "Vanity fair and Jane Eyre," in Quarterly Review, vol. 84 Repr. In Solveig c. Robenson, Ed., December 1848, pp. 153-85.

[12] C. Brontë, Jane Eyre: An autobiography, Leipzig: B. Tauchnitz, 1850, p. 68.

[13] J. Hedgecock, The Femme Fatale in Victorian Literature: The Danger and the Sexual Threat, Amherst, N.Y: Cambria Press, 2008, pp. 25-24.

[14] C. D. Johnson, "That guilty third tier: Prostitution in nineteenth-century American theaters." Victorian Culture in America, vol. 27, no. 5, pp. 575-584, 2010.

[15] C. Selby, Behind the Scenes, or, Actors by Lamplight! A Serio Comicburlesque Burletta, in One Act, etc, London, 1879, p. 5.

[16] H. L. Moore, A Passion for Difference: Essays in Anthropology and Gender, Bloomington [u.a.: Indiana Univ. Press, 1994, p. 12.

[17] T. C. Davis, Actresses as Working Women: Their Social Identity in Victorian Culture, London: Routledge, 1991, p. 12.

[18] K. Maus (1979). Playhouse flesh and blood: Sexual ideology and the restoration actress. ELH, [Online]. 46(4), pp. 595-617. Available: http://www.jstor.org.www.ezplib.ukm.my/stable/2872481

[19] J. P. Collier, History of Dramatic Poetry to the Time of Shakespeare: And Annals of the Stage to the Restoration, (London: John Murray,), vol. 2, pp. 23-24, 1831.

[20] S. Gosson, Plaies Confuted in Five Actions (London, 1582), p. 62.

[21] T. Jordan, "A prologue, to introduce the first woman that came to act on the stage, in the tragedy called The Moor of Venice," in A Royal Arbour of Loyal Poesie, pp. 22, 1664.

[22] J. Perkin, Women and Marriage in Nineteenth-Century England. Chicago, Illinois: Lyceum Books. 1989, pp. 14-262.

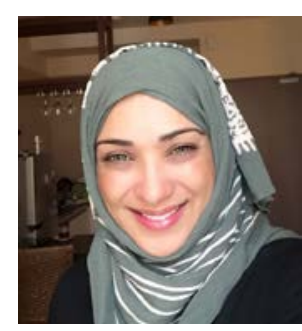

Shada Bokir was born in Aden, Yemen, she is currently a doctorate candidate; the topic of her $\mathrm{PhD}$ dissertation is "The ideology of social taboos on women in controversial Yemeni texts”. Ms. Bokir was working as a university lecturer at Hadhramout University/Yemen until she was awarded the Fulbright scholarship to the United States of America 2009; she earned her master's degree in English literature at Appalachian State University in 2011. Her master's thesis was “A comparative study between Arab writers and Arab western writers in the theme of intercultural love". Her area of interest is sociocultural anthropology and women studies especially in the Middle East and Yemen. She mainly focuses on the impact of the Yemeni literature and photography in conveying the sociocultural structure in the Yemeni society. Ms. Bokir was awarded a scholarship to Malaysia in 2013. She is currently doing her PhD in English literature at the National University of Malaysia (Universiti Kebangsaan Malaysia). 